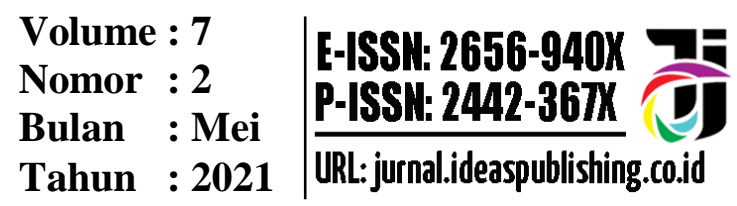

\title{
Akulturasi Budaya Pernikahan Minangkabau dengan Transmigrasi Jawa di Kabupaten Solok Selatan Sumatera Barat
}

\author{
Ona Yulita \\ Khairul Anwar \\ Dody Putra \\ Muhammad Isa
}

Institut Agama Islam Tebo, Jambi, Indonesia

Muhammad Yusup

Institut Agama Islam Nusantara, Batanghari, Indonesia

$$
\begin{gathered}
\text { Pos-el: onayulita@gmail.com } \\
\text { alkhair2505@gmail.com } \\
\text { dodyputra2124088103@gmail.com } \\
\text { isa2019tebo@gmail.com } \\
\text { yusup9253@gmail.com }
\end{gathered}
$$

\section{DOI: 10.32884/ideas.v7i2.333}

\begin{abstract}
Abstrak
Penelitian ini bertujuan untuk mendeskripsikan akulturasi budaya Minangkabau dengan transmigran Jawa dalam perkawinan. Penelitian ini merupakan penelitian etnografi yang akan mendeskripsikan dan menguraikan proses akulturasi budaya perkawinan secara kualitatif. Teknik pengumpulan data dilakukan dengan heuristik, kritik sumber, sintesis, dan interpretasi. Hasil penelitian menunjukkan bahwa akulturasi budaya perkawinan suku Minangkabau dengan transmigrasi Jawa di Kabupaten Solok Selatan-Sumatera Barat telah terlaksana dengan baik. Selain itu, akulturasi dalam perkawinan diterapkan dari penerapan adat dalam perkawinan dengan menggunakan adat campuran, sedangkan dalam resepsi perkawinan kedua mempelai juga mengenakan pakaian adat Minangkabau dan Jawa.
\end{abstract}

\section{Kata Kunci}

akulturasi, budaya, pernikahan, transmigrasi, Sumatera Barat

\section{Abstract}

This research is aimed to describe the acculturation of Minangkabau culture with Javanese transmigrants in marriage. This research was an ethnography research that would be described and elaborated the process of acculturation of marriage culture qualitatively. Data collection techniques are carried out by heuristics, source criticism, synthesis, and interpretation. The results showed that the acculturation marriage culture of Minangkabau with Javanese transmigration in South Solok Regency-West Sumatra was done well. Besides, the acculturation in marriage applied from the application of customs in marriage using mixed customs, while in wedding receptions, the bride and groom wear traditional clothes of Minangkabau and Javanese as well.

\section{Keywords}

Acculturation, culture, wedding, transmigration, West Sumatera

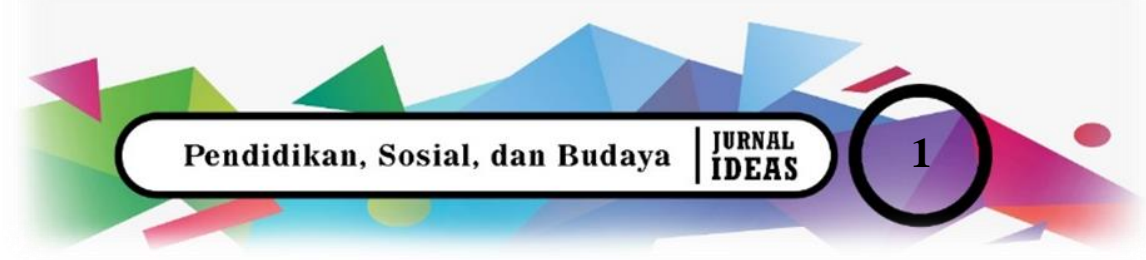




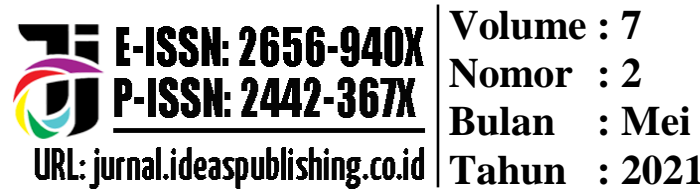

\section{Pendahuluan}

Sejarah terjadinya transmigrasi di Indonesia bermula dari kedatangan kolonial Belanda tahun 1905-1941 M. Transmigrsai ini terjadi dilatarbelakangi beberapa sebab di antaranya yaitu, pertama, program politik etis yaitu mengurangi jumlah penduduk setempat yang padat dan memperbaiki kehidupan ke arah yang lebih baik dari sebelumnya. Kedua, kepemilikan tanah di Pulau Jawa mengalami perubahan, yaitu semakin sempit diakibatkan pertambahan penduduk yang cepat. Hal ini berimbas pada taraf hidup penduduk di Pulau Jawa semakin menurun. Ketiga, meningkatnya kebutuhan tenaga kerja di perusahaan swasta dan di daerah-daerah perkebunan serta pertambangan di luar Pulau Jawa. Selain itu, migrasi terjadi karena masyarakat ingin memperoleh mata pencarian yang lebih baik. Hal ini dilakukan sebagai jalan untuk mencari keamanan dan merupakan upaya menyelamatkan diri dari konflik sosial, serta sebagai upaya adaptasi terhadap iklim (Heriyati dkk., 2020).

Melihat transmigrasi sebagai tujuan utama dalam kebudayaan, maka membuktikan bahwa transmigrasi tidak lagi hanya sekumpulan manusia serta karakteristik demografisya masing-masing tetapi sebagai manusia seperti biasanya yang memiliki kebudayaan atau adat tradisi sendiri, termasuk sistem norma dan sosial. Keterlibatan dalam pendekatan suatu kebudayaan tersebut melihat bahwa transmigrasi merupakan suatu proses perpindahan sumber daya sosial dan budaya. Harapannya adalah terciptanya suatu pembauran dan sosialisasi dengan masyarakat lokal/setempat untuk menjaga tetap kokoh persatuan dan kesatuan bangsa Indonesia.

Padatnya penduduk di Pulau Jawa menarik perhatian pemerintah untuk membuat program penyebaran penduduk dari satu tempat ke tempat lainnya, seperti dari Pulau Jawa ke luar Pulau Jawa. Salah satu tujuannya adalah untuk membuat pemerataan penyebaran penduduk agar tidak menumpuk di satu Pulau Jawa. Daerah-daerah di luar Pulau Jawa yang masih jarang penduduknya diprioritaskan untuk menerima sebaran penduduk dari Pulau Jawa, itulah yang disebut dengan transmigrasi. Adapun daerah tujuan transmigrasi ialah sebagai berikut.

1. Kawasan Pulau Sumatera memiliki beberapa bagian di antaranya Sumatera Utara (Sumut), Sumatera Barat (Sumbar), Sumatera bagian Selatan (Sumsel), daerah Jambi, Bengkulu, Riau, Aceh, serta Lampung.

2. Untuk kawasan Pulau Kalimantan, terdapat beberapa bagian di antaranya Kalimantan 


\section{Volume : 7 \\ Nomor : 2 \\ Bulan : Mei \\ Tahun : 2021

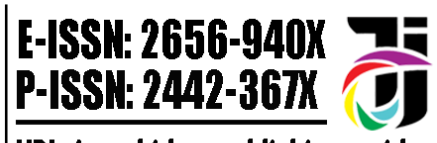 \\ URL: jurnal.ideaspublishing.co.id}

Timur, Kalimantan Selatan, dan Kalimantan Tengah.

3. Pulau Sulawesi, memiliki beberapa bagian yaitu Sulawesi Utara, Sulawesi Tenggara, Sulawesi Tengah, dan Sulawesi Selatan.

4. Pulau Irian, Maluku, NTB (Dinas Kependudukan, 2012).

Transmigran ini dilakukan dengan tujuan demografis, ekonomi, pembangunan, pertahanan dan keamanan, persatuan dan kesatuan bangsa (Sugihen, 1997). Tujuan demografis ini bermakna untuk mengurangi kepadatan dan perbaikan distribusi penduduk, terutama di Pulau Jawa, Madura, dan Bali dengan memindahkan sebagian dari penduduknya ke daerah-daerah lainnya yang penduduknya relatif masih sedikit, seperti Pulau Sumatera, Kalimantan, Sulawesi, serta Irian Jaya.

Transmigrasi yang terjadi di Sumatera Barat termasuk migrasi jarak yang agak panjang, yaitu dibatasi oleh negeri atau wilayahnya, seperti transmigran Jawa, Batak, dan Cina. Program ini sangat menguntungkan bagi daerah yang melepaskan dan daerah yang dituju. Untuk daerah Jawa mengurangi jumlah penduduk yang awalnya padat bisa berkurang, sedangkan daerah yang menerima dapat memenuhi segala kebutuhan tenaga kerja atau transmigran Jawa yang sangat kurang (Iriani, 2018).

Sumatera Barat Kabupaten Solok Selatan pada umumnya didatangi oleh para transmigran Jawa dari tahun 1975 M. Peristiwa tersebut mengakibatkan adat pernikahan masyarakat asli mengalami perubahan. Hal ini disebabkan oleh terjadinya pernikahan antara masyarakat asli dan para transmigran Jawa. Dengan adanya percampuran adat pernikahan dan pembauran antara penduduk asli dan transmigran Jawa, maka penulis menggali tentang bagaimana bentuk akulturasi budaya pernikahan Minangkabau dengan budaya para transmigran khususnya transmigran Jawa.

Penelitian ini bertujuan untuk mengetahui akulturasi tradisi perkawinan Minangkabau dengan transmigran Jawa, serta untuk mengetahui akulturasi budaya dalam tradisi keagamaan; adat pernikahan di Nagari Lubuk Gadang Utara. Akulturasi budaya dapat terjadi pada setiap lapisan masyarakat, termasuk pada masyarakat campuran. Akulturasi terjadi karena adanya komunikasi antarbudaya yang terjadi dalam masyarakat (Suhaimar \& Dewi, 2018).

Akulturasi ialah bentuk keberhasilan dari komunikasi sosial, suatu proses sosial yang timbul disebabkan apabila kelompok masyarakat dengan kebudayaannya dipertemukan dengan kebudayaan asing (Nurdianzah, 2020). Akulurasi budaya di Kabupaten Solok 


\begin{tabular}{l|l} 
Volume : 7 \\
URL: jurnal.ideaspublishing.co.id
\end{tabular} \mid $\begin{aligned} & \text { E-ISSH: 2656-940X } \\
& \text { Nomor : } 2 \\
& \text { Tahun : }: 2021\end{aligned}$

Selatan, terutama antara Minang dan Jawa terjadi secara alami. Ini dimulai dari kehidupan sehari-hari di tengah-tengah masyarakat berbicara menggunakan bahasa Jawa dan bahasa minang, juga ada yang menggunakan bahasa Indonesia. Uniknya, mereka bisa mengerti bahasa masig-masing. Orang Minang ada juga yang berbahasa Jawa halus, biasanya digunakan oleh orang-orang tua atau kalangan ningrat dulunya di tanah Jawa, begitu juga sebaliknya orang Jawa mampu berbahasa Minang.

\section{Metode}

Penelitian ini merupakan penelitian etnografi yang akan mendeskripsikan dan menguraikan proses akulturasi budaya perkawinan secara kualitatif. Teknik pengumpulan data dilakukan dengan heuristik, kritik sumber, sintesis, dan interpretasi. Pada tahap ini, penulis mengumpulkan sumber data dengan tinjauan/penelitian di lapangan melalui wawancara dan observasi ke masyarakat transmigran Jawa dan penduduk asli Nagari Lubuk Gadang Utara Kabupaten Solok Selatan.

Penelitian ini menggunakan dua sumber, yaitu sumber sekunder dan primer. Sumber sekunder diperoleh dari penelitian, buku, dan sumber lainnya tentang transmigrasi yang telah dilakukan dan dipublikasikan oleh orang lain sehingga dapat diperoleh di perpustakaan atau jurnal elektronik. dan juga sumber lainnya yang berkaitan dengan penelitian ini sebanyak mungkin. Sumber primer diperoleh dari wawancara dan observasi (Bungin, 2012). Selanjutnya, menganalisis data yang diperoleh sebelumnya sehingga bisa menafsirkan (interpretasi) sumber-sumber dan menentukan makna yang saling berhubungan dengan sumber-sumber yang didapatkan (Herlina, 2018). Penulis mendeskripsikan akulturasi budaya pernikahan Minangkabau dengan transmigran Jawa menggunakan metode deskriptif analitis.

\section{Hasil dan Pembahasan Hasil}

\section{Adat Budaya Pernikahan Minangkabau}

Adat Minangkabau merupakan warisan budaya. Pelaksanaan adat tersebut dilakukan secara turun-menurun di masyarakat setempat (Bahardur, 2018). Adat Budaya Minangkabau yaitu semua hasil karya, rasa, dan cipta masyarakat Minangkabau yang berkembang seiring dengan perkembangan tatanan sosial masyarakat Minangkabau itu sendiri. 


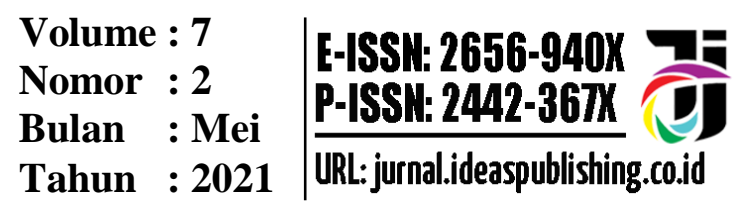

Sebelum para transmigran Jawa masuk ke Lubuk Gadang Utara Kabupaten Solok Selatan, masyarakat membuat aturan tertentu yang mengatur suatu hubungan hidup bermasyarakat atau sering disebut dengan adat istiadat. Agama Islam menyatu dengan adat sesuai dengan pepatah, yaitu “Adat Basandi Syara', Syara' Basandi Kitabullah”. Setelah masuknya transmigran Jawa ke Lubuk Gadang Utara, kebudayaan Minangkabau masih terpelihara dengan baik. Namun, ada beberapa perubahan seperti tradisi pernikahan. Sebagian wilayah di Lubuk Gadang Utara menggunakan adat campuran di dalam pernikahan. Meskipun demikian, pada umumnya para transmigran Jawa yang menggunakan adat dan tradisi Minangkabau dalam pelaksanaan pernikahan.

Setiap daerah Minangkabau berbeda-beda dalam melaksanakan pernikahan. Umumnya, di daerah Minangkabau ada beberapa langkah yang harus dilakukan, di antaranya ialah paresek, manyiriah, dan barundiang, kemudian baru dilaksanakan akad nikah dan selanjutnya dilaksanakan acara pesta pernikahan (baralek). Sementara itu, di Lubuk Gadang Utara Kabupaten Solok Selatan pada umumnya tidak jauh berbeda dalam hal tata cara pelaksanaan perkawinan dibandingkan dengan daerah lainnya di Minangkabau.

Paresek adalah usaha pengenalan pihak keluarga untuk memperkenalkan calon istri kepada calon suami. Pelaksanaan paresek ini tergantung pada masing-masing daerah. Di daerah Pariaman pihak keluarga wanita lebih akif dibandingkan pihak keluarga pria, dikenal dengan istilah "uang jemputan". Berbeda dengan di daerah 50 Koto-Payakumbuh yang dikenal dengan istilah "uang hantaran" dan pihak keluarga pria lebih aktif (Sukmasari, 1986).

Manyiriah atau meminang merupakan kegiatan yang dilakukan oleh pihak pria dengan mengirim utusan kepada pihak wanita dan terkadang sebaliknya. Peminangan ini dilakukan oleh orang tua yang dikepalai oleh Mamak rumah dengan membawa Carano yang berisi siriah dan pinang lengkap, serta jaddah yang terdiri dari nasi dan gulai secukupnya. Kemudian dilanjutkan dengan acara batuka tando (saling menukarkan tanda ikatan janji).

Untuk tahap terakhir sebelum akad pernikahan adalah acara barundiang atau pertemuan untuk membicarakan pelaksanaan upacara perkawinan, yang menyangkut hari pelaksanaan akad perkawinan dan menentukan mengenai jumah barang hantaran atau uang jemputan, serta kapan pelaksanaan pesta perkawinan. 


\begin{tabular}{l|l} 
Eolume : 7 \\
URL: jurnal.ideaspublishing.co.id
\end{tabular} \mid $\begin{aligned} & \text { ESSH: 2656-940X } \\
& \text { Nomor : } 2 \\
& \text { Talan : Mei }: 2021\end{aligned}$

\section{Upacara Sebelum Perkawinan}

\section{Siriah Tanyo}

Jika muda-mudi sudah saling kenal dan sudah sanggup melanjutkan hubungan mereka ke jenjang perkawinan, maka mereka memberitahukan kepada orang tuanya dan selanjutnya dilakukan acara "siriah tanyo".

"Siriah tanyo" adalah kunjungan pihak keluarga pria ke rumah pihak keluarga wanita. Kunjungan tersebut dimaksudkan untuk menyampaikan hasrat mereka yang meminang wanita tersebut. Bila pihak keluarga wanita menerima hasrat mereka, maka dilanjutkan dengan membicarakan tentang kapan waktu akan dilaksanakan acara peminangan (maanta kain). Setelah disepakati harinya, maka langkah selanjutnya adalah melaksanakan acara "maanta kain", sedangkan yang melaksanakan acara "siriah tanyo" ialah para kaum wanita (induak-induak) dan kedua belah pihak.

\section{Maanta Kain}

Acara "maanta kain" ini dilakukan oleh keluarga pihak pria. Dengan kata lain, bahwa pihak keluarga pria datang ke rumah pihak keluarga wanita sambil membawa kain sapatagak (satu setel pakaian) atau cincin. Hal ini dimaksudkan untuk mengikat wanita tersebut. Dengan demikian, wanita tersebut tidak boleh menerima kain dari orang lain lagi (tidak boleh menerima pinangan dari orang lain lagi). Untuk acara "maanta kain", para wanita atau ibu-ibu yang terlibat dengan pihak calon istri.

\section{Baagiah Payo}

"Baagiah payo" adalah pemberitahuan kepada pihak Mamak dan Sumando Nan Sapokok, bahwa si anu telah Maanta Kain atau menerima kain dari si anu. Acara "baagiah payo" ini dilakukan oleh masing-masing keluarga baik dari pihak pria dan wanita.

\section{Bapolok Kunik}

"Bapolok kunik" merupakan musyawarah secara kecil-kecilan dalam rangka menyepakati kapan hari pelaksanaan "maanta tando". Setelah disepakati, kemudian mereka makan bersama. Acara "bapolok kunik" ini biasanya dilakukan pada malam hari. Setelah diketahui kapan hari pelaksanaan “maanta tando”, masing-masing pihak (pihak keluarga wanita dan pria) memberitahukan, kepada mamak-mamak dan ninik mamak, serta urang sumando yang ada di sukunya masing-masing. 


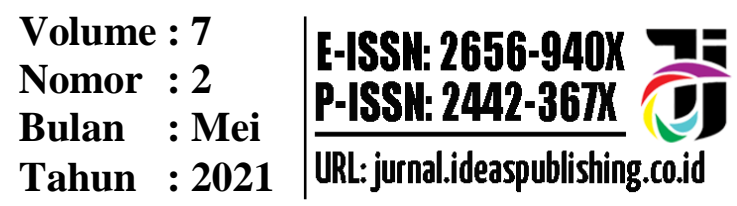

5. Ma'antan Tando

Acara "maanta tando" ini dimaksudkan untuk merundingkan waktu pelaksanaan pernikahan (baralek). Dengan kata lain, semua yang berhubungan dengan pelaksanaan pernikahan dan pestanya dibahas dalam acara maanta tando. Namun, sebelum merundingkan hal di atas, mereka terlebih dahulu melakukan acara "timbang paojean adat pusako" dari kedua belah pihak suku tersebut. Hal ini sering disebut dengan istilah "tando godang". Timbang paojean adat pusako dimaksudkan untuk membuat ikatan janji bahwa tunangan mereka akan dilanjutkan ke jenjang pernikahan. Timbang paojean adat pusako ini merupakan ikatan dalam menjalankan adat, soko, dan pusako. Dengan kata lain, bahwa timbang paojean adat pusako adalah saling menukarkan pusako adat dari kedua belah pihak suku tersebut. Acara ini melibatkan pihak orang tua dan ninik mamak, serta sesepuh dari kedua belah pihak (Alif, 2016).

\section{Pelaksanaan Upacara Perkawinan}

Perkawinan biasanya dilakukan di Masjid. Selain itu, juga dilaksanakan di rumah calon istri. Untuk mahar biasanya seperangkat alat salat atau uang atau yang lainnya tergantung kesepakatan. Yang menjadi saksi diambil satu dari masing-masing mamak dari kedua calon suami dan istri tersebut.

Pelaksanaan pernikahan ini dibimbing oleh angku kali yang sudah mendapat izin dari KUA. Pesta perkawinan (baralek) dilangsungkan pada hari Kamis sampai Jumat, dan seminggu sebelumnya dilakukan acara "mancari kayu", "mangatoan ka urang", dan “batanak santan". Mancari kayu maksudnya ialah mencari kayu bakar untuk masakmemasak selama pesta perkawinan berlangsung. Di samping itu, ada juga yang membuat pondok yang tanpa dinding untuk memasak. Istilah "mangatoan ka urang" di sini aialah memberitahukan ke seluruh orang yang sesuku (mamak-mamak dan ninik mamak) para urang sumando, orang yang bertali darah dengannya dan lapisan bapak-bapaknya (bakolfamily laki-laki bapaknya), serta orang-orang kampung yang dikenalnya meskipun tidak sesuku. Sementara itu, "batanak santan" ialah masak-masak untuk kebutuhan selama pesta perkawinan. Dari ketiga acara tersebut dilakukan oleh masing-masing pihak dari kedua mempelai tersebut di rumah masing-masing.

\section{Pelaksanaan Upacara Setelah Perkawinan}

Maanta sijujuang maksudnya di sini ialah acara pengembalian tando gadang sewaktu acara timbang tando sebelum acara akad nikah. Di dalam acara manta sijujuang ini mereka juga 


\section{ZE E-ISSH: 2656-940X Volume : 7 \\ P-ISSH: 2442-367K Nomor : 2 \\ URL:jurnal.ideaspublishing.co.id Tahun : 2021}

melakukan acara makan bersama di rumah pihak keluarga pria karena pada acara manta sijujuang ini pihak keluarga wanita ke rumah pihak keluarga pria. Jika pengantin perempuan berasal dari suku Minang, maka sepasaran dalam adat Jawa juga dilaksanakan, dalam adat Minang disebut dengan manjalang. Setelah lima hari atau satu minggu demikian, mempelai laki-laki dan perempuan diantar kerumah orang tua mempelai laki-laki oleh orang tua mempelai perempuan, mamak mempelai perempuan, saudara-saudaranya, dan orang yang dituakan.

\section{Adat Pernikahan Transmigran Jawa}

\section{Upacara Sebelum Pernikahan}

Sama halnya dengan adat Minang sebelum upacara pernikahan dilaksanakan, maka yang pertama kali adalah pinang-meminang atau lamaran. Ngelamar berarti orang tua calon pihak laki-laki mengajukan permintaan agar dibolehkan untuk meminang atau mengasuh anak orang lain (Rukmadi \& Warsito, 1979). Acara lamaran dilakukan oleh pihak laki-laki kepada pihak perempuan. Setelah melakukan lamaran, pihak pria memberi tanda pengikat pembicaraan. Tanda pengikat pembicaraan inilah yang disebut dengan peningset.

Tradisi pernikahan adat Jawa menjadi hal yang paling menonjol pada masyarakat Jawa. Bagi mereka, pernikahan dianggap momentum sakral yang terjadi sekali dalam hidup mereka. Oleh sebab itu, dalam pemilihan calon pasangan, masyarakat Jawa sangat teliti dengan mempertimbangkan bibit, bobot dan bebetnya (Wijaya \& Permatasari, 2018).

\section{Pelaksanaan Upacara Pernikahan}

\section{Ijab Kabul atau Akad Nikah}

Pelaksanaan pernikahan atau acara ijab kabul sama dengan adat Minang atau adat lainnya, yaitu pengantin laki-laki mengucapka janji suci atau ijab kabul di depan penghulu yang dipandu oleh petugas Pembantu Pegawai Pencatat Nikah atau yang lebih dikenal dengan nama P3N.

\section{Merias Pengantin}

Sebelum upacara panggih, pengantin dihias. Merias pengantin wanita dimulai sejak pagi sebelum diadakannya acara akad nikah atau ijab kabul. Berbeda dengan merias pengantin pria yang dilaksanakan setelah acara ijab kabul atau akad nikah tersebut. 


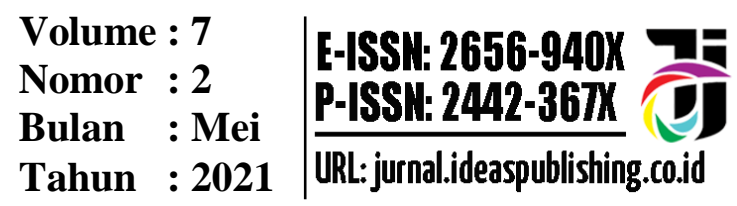

Upacara ini dilakukan di rumah pengantin perempuan. Rangkaian upacara panggih atau temon ini diawali dengan keluarnya pengantin wanita dari dalam rumah untuk meyambut pengantin pria. Pengantin pria berdiri di tengah-tengah panisepuh pria menuju ke tempat bertemu, berhenti dua langkah dari tempat tersebut. Mempelai wanita juga berdiri di tengah-tengah panisepuh, dari pelaminan menuju ke tempat tersebut. Setelah itu, mereka memutar sebanyak tiga atau tujuh kali sambil saling melempar daun sirih yang dicampur dengan beras kuning secara bersamaan. Ini disebut dengan Balangan.

Setelah acara balangan dilanjutkan dengan acara wijik dadi atau injak telur. Mempelai wanita dan laki-laki jalan menuju ke tempat pertemuan. Pengantin wanita membersihkan kaki pengantin pria dengan air bunga. Kegitan tersebut dilakukan setelah pengantin pria menginjak telur sampai pecah. Setelah itu, dilanjutkan membersihkan kaki pengantin pria dengan serbet.

\section{Dahar Kembul, Menjemput Besan, dan Sungkem}

Dahar kembul atau suapan adalah pengantin laki-laki menyuapi pengantin perempuan secara serentak. Setelah itu, mengambil air minum, juga saling menyuapi. Maknanya adalah dalam hidup berkeluarga, mencari nafkah dilakukan bersama-sama, tidak hanya suami saja. Menjemput besan adalah kegiatan yang dilakukan ibu dan bapak pengantin wanita menuju pintu depan untuk menjemput besan. Besan dipersilakan mengambil tempat sebelah kiri dari pengantin wanita.

Kedua orang tua (bapak dan ibu) mempelai pengantin telah duduk di samping kanan pelaminan. Kedua mempelai memberi sungkem, mohon doa restu ke empat orang tua. Makna dari sungkem ini adalah untuk menunjukkan darma bakti anak kepada orang tuanya. Acara sungkem ini bisa membuat hati orang lebih bahagia dan bercampur haru. Oleh karena itu, tidak jarang orang tua yang meneteskan air matanya. Itulah puncak kegembiraan.

\section{Upacara Sesudah Pernikahan}

Satu minggu setelah upacara pernikahan selesai, biasanya pengantin laki-laki tinggal di rumah pengantin perempuan. Hal ini tidak ditentukan lamanya. Sebelumnya diadakannya pesta di rumah pengantin laki-laki (sepasaran). Sementara dalam adat Minang disebut dengan jalang manjalang atau manjalang mintuo. Selain sepasaran, boyongan juga merupakan upacara sesudah pernikahan, yaitu mengajak pengantin

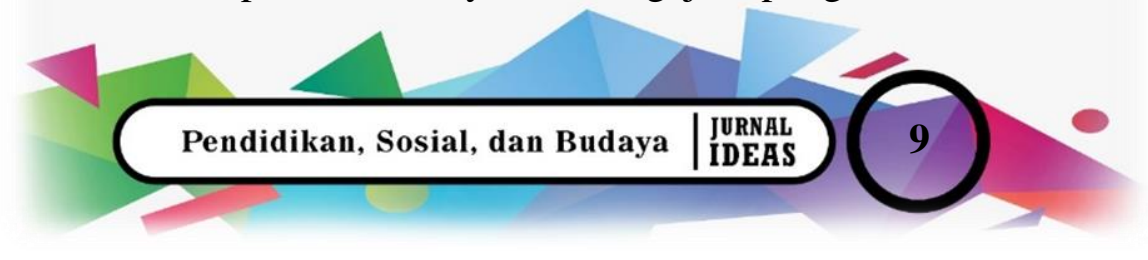




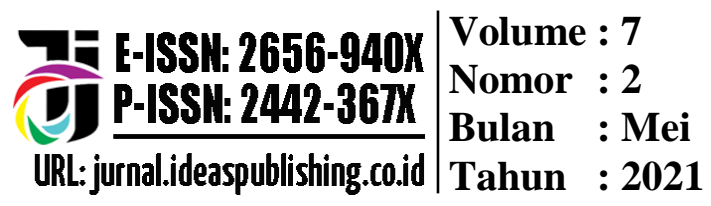

wanita pulang ke rumah pengantin pria. Mereka berdua diantar sanak saudaranya. Pada boyongan ini biasanya kedua pengantin menggunakan pakaian seperti pada saat melangsungkan upacara panggih atau temon.

\section{Pembahasan}

Proses pembauran penduduk asli dengan para transmigran di Lubuk Gadang Utara terjadi melalui jalinan silaturahmi, seperti masyarakat biasa pada umumnya. Selain itu, masyarakat asli ada juga yang melakukan pembauran dengan menikahkan anak mereka, mengangkat jadi saudara dan lain sebagainya.

Akulturasi yang terjadi di Lubuk Gadang Utar, salah satunya terjadi di bidang perkawinan. Perkawinan antara laki-laki Minang dengan perempuan Jawa di Lubuk Gadang Utara Kabupaten Solok Selatan, jarang terjadi karena perempuan tidak mengaku induk kepada suku Minang. Lain halnnya dengan pernikahan antara laki-laki Jawa dan perempuan Minang. Walaupun ada terjadi pernikahan antara perempuan Jawa dan laki-laki Minang, tetapi sangat sedikit jumlahnya. Hal ini disebabkan karena anak yang lahir nantinya tidak memiliki suku, karena dalam adat Jawa anak ikut garis keturunan ayah, sedangkan dalam Minang anak akan ikut suku ibunya. Apabila terjadi pernikahan antara laki-laki Minang dengan perempuan Jawa, maka adat yang digunakan sesuai dengan tempat tinggal mereka atau sesuai dengan adat dimana tempat mereka melangsungkan pernikahan tersebut.

Di Kabupaten Solok Selatan khususnya di daerah Lubuk Gadang Utara, jika terjadi pernikahan silang antara dua suku yang berbeda seperti suku Minang dengan suku Jawa, baik itu laki-lakinya orang minang dan perempuannya orang Jawa, mereka menggunakan adat Minangkabau dalam melaksanakan pernikahan. Hal ini disebabkan karena tempat mereka melangsungkan acara pernikahan, juga ada kesepakatan antara dua belah pihak. Kejadian seperti ini tidak seluruhnya demikian. Namun, di tempat lain ada juga yang menggunakan adat Minang dan adat Jawa di dalam pernikahan sesuai dengan kesepakatan.

Di dalam adat Jawa, acara lamaran dilakukan oleh laki-laki, sedangkan di dalam adat Minang asli sebaliknya, yaitu perempuan yang meminang atau melamar ke rumah pihak laki-laki. Namun, jika terjadi perwakinan silang, maka di sinilah letak akulturasi budaya tersebut, yaitu laki-laki harus melamar ke rumah perempuan, seperti yang seharusnya terjadi di dalam adat Jawa asli. 


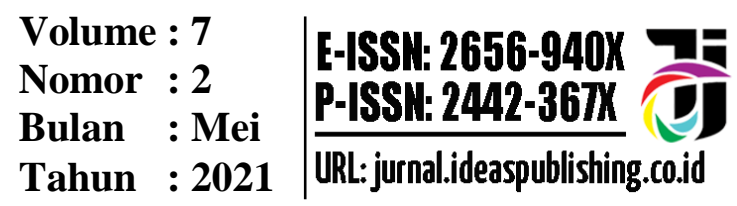

Pernikahan di Lubuk Gadang Utara, perempuan Jawa dan laki-laki Minang biasanya menggunakan adat Jawa ketika pesta pernikahan di rumah pengantin perempuan atau anak daro. Pada saat sepasaran atau pesta di rumah pengantin laki-laki baru dipakai adat Minang. Pada saat pesta dilangsungkan di rumah pengantin perempuan, apabila yang perempuan yang bersuku Jawa, maka adat yang dominan dipakai adalah adat Jawa, seperti malam widodareni dipakai. Namun, calon mempelai laki-laki pada malam widodareni tidak ikut siraman. Pada saat prosesi temu pengantin, semuanya dipakai, seperti panggih, balangan, wijik dadi, sinduran, mangku/nimbang, tanem, kacar kucur, dahar kembul, menjemput besan, dan yang terakhir sungkem. Sementara itu, apabila pengantin perempuannya bersuku Minang, maka malam widodareni tidak dipakai. Kejadian seperti ini terjadi atas kerja sama atau kesepakatan antara kedua belah pihak pengantin.

Pernikahan silang antara suku Minang dan suku Jawa di Lubuk Gadang Utara Kabupaten Solok Selatan pada umumnya di dalam pernikahan menggunakan adat Minangkabau dari adat lamaran sampai setelah pernikahan. Selain itu, masyarakat transmigran Jawa di Lubuk Gadang Utara ada juga yang menggunakan adat campuran, seperti adat Minang dengan adat Jawa di dalam pernikahan. Maksud adat pernikahan campuran di sini ialah pada saat upacara atau pesta pernikahan, seperti pakaian yang digunakan oleh para pengantin, selain menggunakan pakaian adat minang mereka juga menggunakan pakaian adat suku Jawa.

\section{Simpulan}

Faktor yang memengaruhi terjadinya akulturasi budaya dalam praktik pernikahan silang antara suku Minang dengan suku Jawa di Kabupaten Solok Selatan adalah wilayah tempat mereka melangsungkan acara pernikahan, yaitu Minangkabau. Masyarakat transmigran Jawa di Lubuk Gadang Utara menggunakan adat campuran, seperti adat Minang dengan adat Jawa dalam upacara pernikahan. Pakaian yang digunakan oleh pengantin juga menggunakan pakaian adat Minangkabau. Selain itu, mereka juga menggunakan pakaian adat suku Jawa. Hal demikian terjadi sesuai dengan kesepakatan antara dua belah pihak.

\section{Daftar Rujukan}

Alif, M. (2016). "Komunikasi antarbudaya dalam Pernikahan Adat Minangkabau di Kota Banjarbaru." Metacommunication, 1(1). https://doi.org/http://dx.doi.org/10.20527/mc. v1i1.4670. 


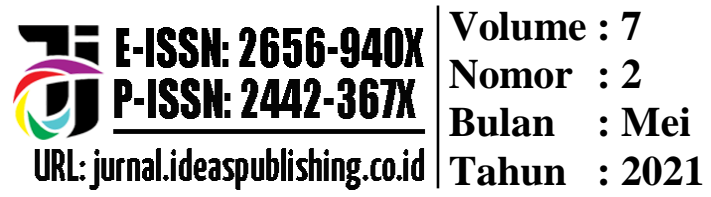

Bahardur, I. (2018). "Kearifan Lokal Budaya Minangkabau dalam Seni Pertunjukkan Tradisional Randai". Jentera: Jurnal Kajian Sastra (Kemdikbud.Go.Id), 7(2). https://doi.org/DOI: https://doi.org/10.26499/jentera.v7i2.932.

Bungin, B. (2012). Analisis Data Penelitian Kualitatif. Bandung: Rajawali Press.

Dinas Kependudukan . (2012). Menuju Era baru Kependudukan Sumatera Barat.

Heriyati, L., Wahyunni, E. S., Saharuddin, \& Hubies, A. V. S. (2020). "Sejarah Migrasi dan Eksistensi Migran Etnis Bugis di Perantauan". Jmb.Lipi, 22(3), 56-66. https://doi.org/https://doi.org/10.14203/jmb.v22i3.787.

Herlina, N. (2018). Metode Sejarah. Bandung: Satya Historika.

Iriani, I. (2018). "Mempertahankan Identitas Etnis: Kasus Orang Jawa di Desa Lestari, Kecamatan Tomoni Kabupaten Luwu Timur". Walasuji, 9(1), 89-100. https://doi.org/https://doi.org/10.36869/wjsb.v9i1.

Nurdianzah, E. (2020). "Akulturasi Budaya dalam Dakwah Sultan Hadirin di Desa Loram Kulon Kecamatan Jati Kabupaten Kudus". Jurnalbpnbsumbar, 6(2), 66-76. https://doi.org/https://doi.org/10.36424/jpsb.v6i2.200.

Rukmadi \& Warsito. (1979). "Adat dan Upacara perkawinan Daerah Adat Jawa Timur". Proyek Penelitian dan Pencatatan Kebudayaan Indonesia.

Shamad, I. A. (2014). Ilmu Sejarah. Padang: Hayfa Press.

Sugihen, B. T. (1997). Sosiologi Pedesaan: Suatu Pengantar. Depok: RajaGrafindo Persada.

Suhaimar, L., \& Dewi, S. F. (2018). "Akulturasi Budaya Pada Perkawinan Etnis Mandailing dan Minangkabau di Nagari Sontang". Journal of Civic Education, 1(2), 116-122. https://doi.org/https://doi.org/10.24036/jce.v1i2.218,

Sukmasari, F. (1986). Perkawinan Adat Minangkabau. Jakarta: Karya Indah.

Wasino, \& Hartatih, E. S. (2018). Metode Penelitian Sejarah. Yogyakarta: Magnum Pustaka Utama.

Wijaya, M., \& Permatasari, A. F. (2018). "Perubahan Perilaku Masyarakat Jawa dalam Penyelenggaraan Resepsi Pernikahan di Kota Surakarta". Jurnal Analisa Soliologi, 2(2), 111-120. https://doi.org/https://doi.org/10.20961/jas.v6i1.18134. 